\title{
Sodium valproate in pregnancy: what are the risks and should we use a shared decision-making approach?
}

\author{
Alastair Macfarlane ${ }^{1 *}$ (D) and Trisha Greenhalgh ${ }^{2}$
}

\begin{abstract}
Background: Despite significant teratogenic risks, sodium valproate is still widely prescribed in many countries to women of childbearing age, as a mood stabiliser in bipolar disorder and also in epilepsy. The UK has recently banned valproate use in women who are not in a pregnancy prevention programme. Whilst this ruling reflects prevailing clinical practice, it also highlights an ongoing debate about when (if ever) a woman who is or could become pregnant should be allowed to choose to take valproate.

Main body: We review the benefits and harms of drugs available for bipolar disorder and epilepsy in women of childbearing age, with a particular focus on teratogenic risk. We speculate on hypothetical rare situations in which potential benefits of valproate may outweigh potential harms in such women. We also review the literature on shared decision-making - on which there is now a NICE guideline and numerous evidence-based decision tools. Drawing on previous work by experts in shared decision-making, we offer a list of 'frequently asked questions' and a matrix of options to support conversations with women about continuing or discontinuing the drug in (or in anticipation of) pregnancy. We also consider whether shared decision-making is an appropriate paradigm when considering whether to continue a teratogenic drug.
\end{abstract}

Conclusion: We conclude that because valproate in pregnancy remains the subject of such debate, there is scope for further research - not only into the relative efficacy and safety of alternatives to it - but also into the dynamics of communication and shared decision-making in this situation.

Keywords: Sodium valproate, Pregnancy, Teratogenicity, Epilepsy, Bipolar disorder, Shared decision-making

\section{Background}

In July 2017, almost 60 years after the thalidomide tragedy [1], the French National Agency for the Safety of Medicines and Health Products (ANSM) imposed a nationwide ban on the use of sodium valproate in pregnancy, on the grounds of teratogenicity [2]. Guidelines produced by the UK Royal College of Obstetricians and Gynaecologists in 2016 recommended avoiding this drug in any woman of child-bearing potential [3] (reflecting a previous NICE guideline published in 2014 [4]). More recently, regulatory bodies have tightened their stance significantly. In February 2018, for example, the Pharmacovigilance Risk Assessment Committee of the European

\footnotetext{
* Correspondence: alastair.macfarlane@nhs.net

${ }^{1}$ Academic Foundation Year 1 Doctor, Barnet Hospital, Wellhouse Lane,

Barnet EN5 3DJ, UK

Full list of author information is available at the end of the article
}

Medicines Agency recommended that valproate should not be used in pregnancy unless the woman has a form of epilepsy that is unresponsive to other anti-epileptic drugs, and also that the drug should not be prescribed for women of childbearing age who are not enrolled in a pregnancy prevention programme [5]. In April 2018, the UK Medicines and Healthcare Devices Regulatory Agency endorsed this recommendation [6].

Sodium valproate is a medication licensed for both epilepsy [7] and bipolar disorder [8], and is also used off label for a range of indications including migraine prophylaxis [5]. Whilst its use in epilepsy is falling in the $\mathrm{UK}$ as the use of third-generation anticonvulsants increases $[9,10]$, its use for bipolar disorder has been increasing, especially among women of childbearing age [11]. In Ireland, recent data corroborate these findings

(c) The Author(s). 2018 Open Access This article is distributed under the terms of the Creative Commons Attribution 4.0 International License (http://creativecommons.org/licenses/by/4.0/), which permits unrestricted use, distribution, and reproduction in any medium, provided you give appropriate credit to the original author(s) and the source, provide a link to the Creative Commons license, and indicate if changes were made. The Creative Commons Public Domain Dedication waiver (http://creativecommons.org/publicdomain/zero/1.0/) applies to the data made available in this article, unless otherwise stated. 
[12], which necessitate increased surveillance and an improved understanding of alternatives [13].

Bipolar disorder is a psychiatric condition characterised by alternating periods of elated mood and depression [14]. The condition is a significant public health problem worldwide, and remains a challenge for patients and clinicians [15]. Systematic reviews examining the epidemiology of bipolar disorder show that it is associated with markedly increased suicide and self-harm rates [16], substance abuse [17] and other psychiatric morbidities [18-21]. Given the female preponderance and young age of onset of bipolar disorder (17.5 years) [22], women of childbearing age make up a significant proportion of patients. Management of bipolar disorder is difficult in this group, as many mood stabilisers have either been shown to be teratogenic or have unknown effects in pregnancy (see below) [23].

Epilepsy is a condition characterised by abnormal excessive synchronous neuronal activity in the brain causing seizures [24], and is associated with a variety of neurobiological, psychological, social and cognitive consequences. The prevalence of active epilepsy in adults is $5-10$ per 1000 , and is influenced by many factors, both genetic and environmental [25]. One risk factor for seizure activity is oestrogen [26], hence pregnancy can increase the seizure rate [27]. Information from EURAP, the International Registry of Anti-Epileptic Drugs and Pregnancy, suggests that $20 \%$ of pregnant patients with epilepsy were treated with valproate from 1999 to 2004, despite knowledge of its teratogenic risks [27]. A more recent study in the UK showed that valproate made up $25 \%$ of anti-epileptic drug prescriptions in pregnancy [28].

This article will explore the benefits and harms of sodium valproate and its alternatives in current or planned pregnancy in the context of a tightening regulatory system for this drug. We will suggest questions that should guide decision-making for these patients, and address the crucial issue of whether and how patients can be involved as democratic partners in such decisions.

\section{Main text \\ Mood stabilisers in bipolar disorder}

Mood stabilisers are the mainstay of pharmacological management in patients with bipolar disorder. Although there is some contention about what exactly constitutes a mood stabiliser [29], the defining feature is that these drugs improve both manic and depressive symptoms without significantly worsening either polarity [8]. Some drugs may be of benefit in patients with bipolar disorder but are not classed as mood stabilisers because of their ability to precipitate mania (e.g. some antidepressants) or worsen depression (e.g. some antipsychotics).

Table 1 shows the main classes of mood stabiliser used in the treatment of bipolar disorder. Sodium valproate, a mood stabiliser of the anticonvulsant class, is commonly prescribed for the treatment of mania and the prophylaxis of bipolar disorder [30]. A systematic review assessing valproate efficacy in acute mania showed that it has a has a number needed to treat (NNT) of between 2.3 and 4.3 [31], and may be used in patients who have

Table 1 Main classes of mood stabiliser (and alternatives to valproate in the treatment of bipolar disorder), mechanisms of action and side effects (not including foetal or maternal risks). Compiled from various sources [10, 33, 34, 91-100]

\begin{tabular}{|c|c|c|c|}
\hline Class & $\begin{array}{l}\text { Medication } \\
\text { name }\end{array}$ & Proposed mechanism(s) of action & Side effects \\
\hline Mineral & Lithium & $\begin{array}{l}\text { Enhances serotonergic neuron activity, inhibits } \\
\text { pAp-phosphatase enzyme, interacts with nitric } \\
\text { oxide signalling activity }\end{array}$ & $\begin{array}{l}\text { Common: Gl upset, fine tremor, polyuria, polydipsia, metallic } \\
\text { taste in mouth, ankle oedema, weight gain. Chronic: renal } \\
\text { toxicity, hypothyroidism. }\end{array}$ \\
\hline \multirow[t]{3}{*}{$\begin{array}{l}\text { Anti- } \\
\text { epileptics }\end{array}$} & $\begin{array}{l}\text { Sodium } \\
\text { valproate }\end{array}$ & $\begin{array}{l}\text { GABA potentiation, blocks voltage gated sodium } \\
\text { channels, epigenetically inhibits histone } \\
\text { deacetylase }\end{array}$ & $\begin{array}{l}\text { Common: Gl upset, hyperammonaemia (causing nausea), } \\
\text { weight gain, tremor, hair loss with curly regrowth. } \\
\text { In women: polycystic ovarian syndrome, hyperandrogenism. } \\
\text { Rare: fulminant liver failure. }\end{array}$ \\
\hline & Lamotrigine & $\begin{array}{l}\text { GABA potentiation, suppresses glutamate release, } \\
\text { inhibits serotonin reuptake }\end{array}$ & $\begin{array}{l}\text { Common: tremors, dizziness, tiredness, loss of co-ordination, } \\
\text { menstrual disturbance, dry mouth, sleep problems. }\end{array}$ \\
\hline & Carbamazepine & Blocks voltage gated sodium channels & $\begin{array}{l}\text { Common: dizziness, diplopia, drowsiness, ataxia, nausea, } \\
\text { headaches, dry mouth, oedema, hyponatraemia, erythematous } \\
\text { rash, sexual dysfunction. } \\
\text { Rare: agranulocytosis. }\end{array}$ \\
\hline \multirow{4}{*}{$\begin{array}{l}\text { Atypical } \\
\text { antipsychotics }\end{array}$} & Risperidone & \multirow{3}{*}{$\begin{array}{l}\text { Dopaminergic }\left(\mathrm{D}_{1-5}\right) \text { receptor antagonist, } \\
\text { serotonergic }\left(5-\mathrm{HT}_{2 \mathrm{~A} / \mathrm{C}}\right) \text { receptor antagonist }\end{array}$} & \multirow{3}{*}{$\begin{array}{l}\text { Common: sexual dysfunction (hyperprolactinaemia). } \\
\text { Long term: movement disorders (e.g. tardive dyskinesia, } \\
\text { akathisia, parkinsonism), increased risk of cardiovascular } \\
\text { disease. } \\
\text { Rare: neuroleptic malignant syndrome }\end{array}$} \\
\hline & Olanzapine & & \\
\hline & Quetiapine & & \\
\hline & Aripiprazole & $\begin{array}{l}\text { Dopaminergic }\left(\mathrm{D}_{2}\right) \text { and serotonergic }\left(5-\mathrm{HT}_{1 \mathrm{~A}}\right) \\
\text { receptor partial agonist }\end{array}$ & $\begin{array}{l}\text { Common: weight gain, headache, agitation, insomnia, } \\
\text { gastrointestinal effects, disinhibition. }\end{array}$ \\
\hline
\end{tabular}


either failed to respond to lithium [32], or those who do not tolerate it [33]. Prophylactically, the NNT to prevent manic and depressive episodes respectively is 21.3 and 10.5 [34].

Valproate has a number of side effects other than risks to the mother and foetus, which are summarised in Table 1. In any patient, these side effects must be weighed against the significant risks associated with untreated mania or bipolar disorder, including suicide [16].

A high proportion of patients with bipolar disorder will face the scenario of needing to manage their illness during an anticipated or current pregnancy [22]. This raises a very difficult clinical issue: managing the mental health needs of the mother whilst minimising the teratogenic risk to the developing foetus. Bipolar disorder per se does not increase the risk of malformation or foetal death [35], but several mood stabilisers are associated with major teratogenicity.

All psychotropic medications cross the placenta [36]. As well as the recognised risk of teratogenicity - which occurs in the first trimester during organogenesis there are further ways in which these medications may adversely affect a pregnancy. Viguera et al. categorise the effects of psychotropic medication use in pregnancy into: [1] obstetric complications (such as low birth weight), [2] perinatal complications (occurring shortly after birth) and [3] long-term neurological and behavioural sequelae (such as autism) [23]. Table 2 summarises the main foetal and maternal risks associated with mood stabilisers.

\section{Anti-epileptic drugs}

In epilepsy as in bipolar disorder, valproate is not the only available drug for women of childbearing age. And again, there is a somewhat complex picture of efficacy and safety in the different alternatives. Schmidt and Schachter recently reviewed drug treatment for epilepsy [10], and highlighted that epilepsy is not a single condition but an umbrella term encompassing different underlying pathologies and clinical manifestations. Different kinds of epilepsy respond to different drugs and in the $20-30 \%$ of cases that are refractory, multiple drugs need to be used in combination. Getting the right drug for a person with epilepsy involves balancing benefits and side effects as well as taking account of lifestyle issues and personal preferences [37].

Table 3 summarises the main anti-epileptic drugs that could be offered to a woman of childbearing age. Whilst valproate (first licensed in 1967) is no longer the commonest anti-epileptic drug prescribed, it remains one of the most effective. It is still used in emergency settings to control focal and generalised seizures; it may be effective when newer anticonvulsants have not worked; and it is the recommended first-line therapy for complex partial seizures.

Schmidt and Schachter point out that whilst two in every three women with epilepsy who become pregnant

Table 2 Foetal and maternal risks associated with selected mood stabilisers. Compiled from various sources [50, 53, 78, 79, 101-106]

\begin{tabular}{|c|c|c|}
\hline Medication & Risks to offspring associated with use in pregnancy & Maternal risks associated with use in pregnancy \\
\hline Lithium & $\begin{array}{l}\text { Severe toxicity in newborn. There are limited and conflicting data } \\
\text { regarding the risk of cardiovascular malformations (including } \\
\text { Ebstein's anomaly) following lithium exposure in utero. A large } \\
\text { cohort study in } 2017 \text { showed that the relative risk was still } \\
\text { elevated (1.7), and also dose dependent, but lower than } \\
\text { previously thought. Absolute risk remains low }(<1 / 1500) \text {. } \\
\text { Non-teratogenic associations include low birth weight, cyanosis, } \\
\text { bradycardia, Gl bleeding, polyhydramnios, seizures. }\end{array}$ & $\begin{array}{l}\text { Renal lithium clearance rises during pregnancy, so levels need to } \\
\text { be monitored regularly to maintain therapeutic levels. }\end{array}$ \\
\hline Valproate & $\begin{array}{l}\text { Significantly elevates the risk of major defects ( } 7 \text { times higher). } \\
\text { These include spina bifida, atrial septal defect, cleft palate, } \\
\text { hypospadias, polydactyly and craniosynostosis. See Table } 4 \text { and } \\
\text { main text for further details. } \\
\text { Non-teratogenic associations include case reports of intra-uterine } \\
\text { growth restriction, infant hepatic toxicity and foetal distress dur- } \\
\text { ing labour. } \\
\text { Neurodevelopmental associations - foetal exposure to valproate } \\
\text { in utero is associated with } 1.7 \text { times risk of autism spectrum } \\
\text { disorder. }\end{array}$ & $\begin{array}{l}\text { Increased hepatic clearance of valproate and increased apparent } \\
\text { volume of distribution cause lower maternal levels of the drug. }\end{array}$ \\
\hline Carbamazepine & $\begin{array}{l}\text { Risk of major congenital abnormalities increased } 1.8 \text { times, } \\
\text { including malformations of neural tube, urinary tract and } \\
\text { cardiovascular system, and cleft palate. }\end{array}$ & $\begin{array}{l}\text { Crosses placenta and lowers maternal serum levels, so doses } \\
\text { may need to be increased. }\end{array}$ \\
\hline Lamotrigine & $\begin{array}{l}\text { Conflicting evidence on the risk of malformations, especially } \\
\text { regarding dose response. } \\
\text { Evidence emerging that it appears to be a relatively safe drug in } \\
\text { pregnancy. }\end{array}$ & $\begin{array}{l}\text { Crosses placenta and lowers maternal serum levels, so dose may } \\
\text { need to be increased. Dizziness, diplopia and ataxia have been } \\
\text { reported following these dose increases in pregnant women. }\end{array}$ \\
\hline $\begin{array}{l}\text { Atypical } \\
\text { antipsychotics }\end{array}$ & $\begin{array}{l}\text { Most do not appear to significantly increase malformation rate. } \\
\text { Risperidone requires additional study. }\end{array}$ & $\begin{array}{l}\text { Crosses placenta and lowers maternal serum levels, so doses } \\
\text { may need to be increased. }\end{array}$ \\
\hline
\end{tabular}


Table 3 Selected anti-epileptic drugs (and alternatives to valproate in the treatment of epilepsy), adapted from Schmidt and Schachter [10]

\begin{tabular}{|c|c|c|c|c|}
\hline $\begin{array}{l}\text { Class of } \\
\text { drug }\end{array}$ & Name of drug & Proposed mechanism & Side effects & Additional information \\
\hline \multirow[t]{2}{*}{$\begin{array}{l}\text { 1st } \\
\text { generation }\end{array}$} & Phenytoin & Sodium channel blocker & $\begin{array}{l}\text { Enzyme inducer (hence interaction } \\
\text { with other medications), skin } \\
\text { hypersensitivity }\end{array}$ & $\begin{array}{l}\text { First line for focal and generalised seizures } \\
\text { with focal onset }\end{array}$ \\
\hline & Ethosuxamide & T-type calcium channel blocker & $\begin{array}{l}\text { Gastrointestinal side effects, } \\
\text { insomnia, psychosis }\end{array}$ & First line for absence seizures \\
\hline \multirow[t]{2}{*}{$\begin{array}{l}\text { 2nd } \\
\text { generation }\end{array}$} & Carbamazepine & Sodium channel blocker & $\begin{array}{l}\text { Enzyme inducer, skin } \\
\text { hypersensitivity }\end{array}$ & $\begin{array}{l}\text { First line for focal and generalised seizures } \\
\text { with focal onset }\end{array}$ \\
\hline & Valproate & $\begin{array}{l}\text { GABA potentiation, blocks voltage } \\
\text { gated sodium channels, } \\
\text { epigenetically inhibits histone } \\
\text { deacetylase }\end{array}$ & $\begin{array}{l}\text { Gl upset, weight gain, tremor, hair } \\
\text { loss with curly regrowth, } \\
\text { teratogenicity (see Table 4) } \\
\text { In women: polycystic ovarian } \\
\text { syndrome, hyperandrogenism } \\
\text { Rare: fulminant liver failure }\end{array}$ & $\begin{array}{l}\text { First line for focal and generalised seizures, } \\
\text { no skin hypersensitivity, no newer drugs } \\
\text { have been shown to have higher efficacy }\end{array}$ \\
\hline \multirow[t]{6}{*}{$\begin{array}{l}\text { 3rd } \\
\text { generation }\end{array}$} & Vigabatrin & GABA potentiation & $\begin{array}{l}\text { Visual defects, weight gain, seizure } \\
\text { aggravation, encephalopathy }\end{array}$ & $\begin{array}{l}\text { Use in infantile spasms, adjunct in complex } \\
\text { partial seizures }\end{array}$ \\
\hline & Lamotrigine & $\begin{array}{l}\text { GABA potentiation, suppresses } \\
\text { glutamate release, inhibits } \\
\text { serotonin reuptake }\end{array}$ & $\begin{array}{l}\text { Tremor, dizziness, tiredness, loss of } \\
\text { co-ordination, menstrual disturb- } \\
\text { ance, dry mouth, sleep problems }\end{array}$ & $\begin{array}{l}\text { First line for focal and generalised seizures, } \\
\text { lower efficacy than valproate for absence } \\
\text { seizures }\end{array}$ \\
\hline & Oxcarbazepine & Sodium channel blocker & $\begin{array}{l}\text { Enzyme inducer, hyponatraemia, } \\
\text { skin hypersensitivity }\end{array}$ & $\begin{array}{l}\text { First line for focal and generalised seizures } \\
\text { with focal onset }\end{array}$ \\
\hline & Gabapentin & Calcium channel blocker & $\begin{array}{l}\text { Weight gain, psychosis, seizure } \\
\text { aggravation, tiredness, dizziness }\end{array}$ & $\begin{array}{l}\text { Adjunctive use only, used in focal and } \\
\text { generalised seizures with focal onset }\end{array}$ \\
\hline & Levetiracetam & SV2A modulation & $\begin{array}{l}\text { Tiredness, dizziness, behavioural } \\
\text { problems }\end{array}$ & $\begin{array}{l}\text { First line in focal and generalised seizures } \\
\text { with focal onset and myoclonic seizures. }\end{array}$ \\
\hline & Topiramate & $\begin{array}{l}\text { GABA potentiation, glutamate } \\
\text { inhibition, sodium/calcium channel } \\
\text { blocker }\end{array}$ & $\begin{array}{l}\text { Tiredness, dizziness, skin } \\
\text { hypersensitivity, weight loss, } \\
\text { teratogenicity }\end{array}$ & First line for focal and generalised seizures \\
\hline
\end{tabular}

remain seizure free throughout their pregnancy, antiepileptic drug dosages may need to be adjusted as the pregnancy progresses, particularly when seizures occur in the first trimester. Women taking lamotrigine, levetiracetam, topiramate, and oxcarbazepine may need an increase in dose to compensate for pregnancy-related increase in clearance of these drugs so as to reduce the risk of breakthrough seizures. These authors also highlight the small increased risk that the children of women who take an antiepileptic drug during pregnancy will be small for gestational age and have a lower Apgar score.

\section{A woman of childbearing age taking valproate...}

There are two conceivable scenarios when a woman taking valproate would have the dilemma of continuing it during pregnancy: [1] she is planning to become pregnant whilst taking valproate; or [2] she has already become pregnant whilst taking valproate. Both these scenarios are currently fairly common in both primary and secondary care [38]. In addition to the fact that both bipolar disorder and epilepsy are common in women of childbearing age [15], patients suffering from bipolar disorder are at increased risk of unintended pregnancy for various reasons, including sexual disinhibition associated with mania [30].

Within these two scenarios, several factors might affect the clinical outcome for both mother and child: the severity of the condition (including frequency and duration of relapses), co-existing medication (including the need for combination therapy to control the bipolar disorder or epilepsy), drug and alcohol use, co-morbidity, sociocultural factors, level of social support; and also (in the second scenario) the stage at which the pregnancy was confirmed.

Deciding whether or not to continue valproate in these situations requires a complex risk assessment. Many studies over the years have assessed the sequelae of continuation and discontinuation of valproate - both to mother and child. We review these below.

\section{Risks of continuation}

Prospective controlled trials on the effects of valproate during pregnancy are limited for obvious reasons, but cohort studies have shown that women who reported using the medication during the first trimester of pregnancy had a seven-fold higher risk of congenital malformations compared to the baseline rate of $1.62 \%$ [39]. Indeed, the relative risk of valproate on major defects is 
so high, and these defects are so characteristic, that the term 'foetal valproate syndrome' has been described [40]. Reasons for the teratogenic effects are not fully understood, but possibly involve epigenetic effects, including the inhibition of histone deactylase with associated changes in gene expression [41], increases in foetal oxidative stress, or the antagonism of folate required for DNA synthesis [42].

As well as its teratogenic effects, valproate may lead to problems after birth, including immediate withdrawal effects such as jitteriness [40]. Valproate therapy during pregnancy has been shown to correlate with longer-term neurodevelopmental problems leading to repetitive behaviours, impaired communication and social isolation [43, 44], as well as reduced IQ [45]. These autistic-like traits have been demonstrated in both animal models $[46,47]$ and human studies, affecting around $40 \%$ of children exposed to valproate $[48,49]$. Actual diagnoses of autism spectrum disorder are lower, however, at around 4\% [50]. Although the mechanisms underlying these are yet to be elucidated, there is a possible link with lower cell density in the cerebellum [51], associated with mutations in the PTEN gene [52].

The risk of valproate use in pregnancy on specific malformations has been quantified. Table 4 shows the odds ratio of different malformations based on an extensive review of the research literature [53]. Risk of malformation increases with drug dose and with combination therapy [54-56].

Considerations about continuation should also address drug-related risks to the mother. Full blood count and liver function tests, for example, should be measured regularly to rule out blood dyscrasias or liver pathology [30].

\section{Risks of discontinuation}

There are risks associated with discontinuing valproate in a patient whose bipolar disorder or epilepsy is well controlled. Viguera et al. found that pregnant women with bipolar disorder who were euthymic at conception but stopped mood stabilisers were twice as likely to

Table 4 Odds ratios and absolute risk of congenital malformation with sodium valproate (adapted from Jentink) [53]

\begin{tabular}{lll}
\hline Condition & $\begin{array}{l}\text { Odds ratio } \\
\text { (median and range) } \\
\text { in offspring of mothers } \\
\text { who took valproate in pregnancy }\end{array}$ & \\
\hline Spina bifida & $12.7(7.7-20.7)$ & $0.6 \%$ \\
Atrial septal defect & $2.5(1.4-4.4)$ & $0.5 \%$ \\
Cleft palate & $5.2(2.8-9.9)$ & $0.3 \%$ \\
Hypospadias & $4.8(2.9-8.1)$ & $0.7 \%$ \\
Polydactyly & $2.2(1.0-4.5)$ & $0.2 \%$ \\
Craniosynostosis & $6.8(1.8-18.8)$ & $0.1 \%$ \\
\hline
\end{tabular}

relapse than those who continued mood stabilisers, and the median time until first recurrence was four times shorter [57]. If the mood stabiliser was discontinued abruptly, recurrence latency was eleven times shorter. Most studies of mood stabiliser discontinuation during pregnancy have been on lithium withdrawal [58-60]; specific evidence on discontinuing valproate in pregnancy is sparse. However, evidence for valproate withdrawal outside of pregnancy illustrates similar trends: relapse rates are high, especially during abrupt withdrawal [61-63], and there is even a case report of one patient being treated for epilepsy developing new-onset mania following valproate withdrawal [64].

Discontinuation can also be problematic in epilepsy. Observations from the EURAP study showed that withdrawal of valproate in the first trimester (when it is most teratogenic) was associated with a significantly higher rate of generalised tonic clonic seizures (33\%) compared to when it was continued (16\%) [65]. More striking, however, is that the rate of seizures was also elevated (29\%) when valproate was switched to another anti-epileptic medication.

Another consideration for bipolar disorder patients should include the risks of puerperal psychosis. Prevalence of this condition in the general population is about $0.1-0.25 \%$, but may be up to $50 \%$ in women with bipolar disorder [66]. Hospitalisation for psychiatric morbidity predicts the risk of puerperal psychosis [67], so untreated bipolar disorder may not just affect the mother during pregnancy, but also in the weeks afterwards.

Psychosis during the perinatal period must be viewed in a broader context: leaving it untreated can cause harm to the mother through poor self-care, increased drug and alcohol use, non-attendance for obstetric care and impulsive acts [30]. In severe cases, there may be direct harm to the child through untreated maternal psychomorbidity, including neglect or even infanticide [68, 69]. A 20-year study on puerperal psychosis in Austria found that out of 96 patients, six died from suicide, with three 'extended suicide attempts' leading to two cases of infanticide [70]. Furthermore, severe mental health issues during and soon after pregnancy can adversely impact the child's emotional, cognitive and physical health later in life [71]. The child may be removed from the care of the mother for safeguarding reasons, leading to problems with bonding.

In sum, whilst there are good reasons to minimise the use of sodium valproate in pregnancy, it is theoretically possible that in some individual cases, the risks of discontinuing the drug could outweigh the benefits.

Pregnancy prevention programmes and valproate A 'pregnancy prevention programme' is defined by the new UK regulations on valproate prescribing as follows [5]: 
1. There must be an assessment of the woman's potential to become pregnant and pregnancy tests before and during treatment.

2. The woman must be offered counselling about the risk of valproate to her unborn child and the importance of using effective contraception while taking the drug.

3. Review by a specialist is now mandatory, and women taking valproate will be required to have annual specialist reviews including completing a risk acknowledgement form.

4. The packaging for valproate will carry a visual warning of the risks associated with pregnancy. Pharmacists will be required to discuss the risks and issue a warning card every time they dispense valproate to women of childbearing age.

Many of these steps reflect what has become accepted good practice in several countries over the past few years $[4,72]$, but they are now becoming mandatory in the UK. Clinicians generally avoid starting women of childbearing age on valproate, but when this is viewed as clinically unavoidable, information and a discussion about risks, along with an offer of contraception, are a core component of care.

Whilst the new requirements are therefore in line with current recommended best practice, there is also evidence suggesting an evidence-practice gap. For example, a recent study in the UK showed that around half the women taking sodium valproate were unaware of its potential to damage the foetus [73]. A literature review on management of women with substance-use disorders found that unplanned pregnancy was common but also that access to long-acting reversible contraception through integrated contraception services was an effective approach to targeting this problem [74]. We could learn from approaches taken in low-income countries, such as the implementation of post-abortion contraception in Zimbabwe, which has significantly decreased unplanned pregnancy rates in women with mental health conditions [75].

The above measures will only be relevant, of course, if the woman finds it acceptable to prevent pregnancy. In many women, there comes a time when pregnancy is desired. The clinician should explain to the women that whilst it is never possible to promise a healthy baby, the chances of this happening will be best if the pregnancy is carefully planned, including adjusting medication in the pre-conception period - which in the UK must (with rare exceptions) involve discontinuation of valproate. Women should be encouraged to report a pregnancy as soon as the test is positive - and reassured that the doctor will not be judgemental even if the pregnancy was "unplanned".
Patients with bipolar disorder who are already taking valproate and are planning pregnancy have two options: (1) withdraw valproate slowly prior to conception, with close monitoring of their mental health status, or (2) switch to a lower-risk mood stabiliser. The first option needs to be carried out cautiously to minimise risk of relapse, and the decision to do this should take into account past history of relapse, co-existing medications and any protective or predisposing risk factors.

The second option reduces the risk of maternal psychomorbidity during pregnancy, but with a higher risk to the foetus. Although the most commonly prescribed mood stabilisers (lithium, carbamazepine and valproate) are associated with foetal abnormalities - albeit to differing extents - current evidence on lamotrigine and atypical antipsychotics is more favourable [36].

Various studies have looked at the safety of lamotrigine use in pregnancy, particularly regarding its dose. Tomson et al..., using the EURAP data, found differences in the malformation rates in patients given $<300 \mathrm{mg} /$ day and $\geq 300 \mathrm{mg} /$ day (2 and $4.5 \%$ respectively) [76]. Campbell et al, using data from the UK Epilepsy and Pregnancy Register, found no significant relationship between dose and malformation rate, and concluded that whilst lamotrigine has a favourable profile compared with valproate for adverse pregnancy outcomes, the requirements for seizure control should not be overlooked'.

Atypical antipsychotic drugs may be used in the management of bipolar disorder and are typically recommended for short-term use [77]. In a review of treatment of bipolar disorder in pregnancy, Grover and Avasthi cite numerous studies with differing findings on the safety profiles of olanzapine, risperidone, quetiapine, amisupiride, ziprasidone, aripiprazole and clozapine, but conclude that these drugs are nonetheless safer than lithium or valproate in pregnancy [36]. A recent large cohort study in the United States showed that antipsychotic use early in pregnancy does not 'meaningfully increase the risk for congenital malformations overall or cardiac malformations in general' [78]. Risperidone carries a small increased risk, and requires additional study.

A recent letter in the BMJ highlighted that as the warnings regarding valproate use in pregnancy are justifiably being strengthened, it is very important to search for safer alternatives [79]. Nevertheless, we should not underestimate the difficulty of interpreting observational data on medication effects during pregnancy.

\section{How to minimise valproate use during pregnancy}

The most difficult clinical decisions may arise when a patient using valproate presents when already pregnant. Presentations later in pregnancy and those in women on higher doses of valproate are associated with an increased risk of foetal abnormalities [56]. Current recommendations 
are to withdraw the drug if possible, and especially during the first trimester [49]. However, in a systematic review examining the risk of bipolar disorder recurrence following discontinuation of mood stabilisers, the authors concluded that in women with unstable forms of the disease, the high risk of relapse associated with rapid withdrawal of mood stabilisers more than balanced the potential risk to the foetus [80]. This suggests that gradual withdrawal through down-titration of dose is preferable to abrupt discontinuation.

It is possible to conceptualise hypothetical scenarios in which continuation of sodium valproate during pregnancy could be clinically justifiable. For example, if a patient on valproate presents in her final trimester with a history of severe and unstable bipolar disorder, has relapsed during a previous pregnancy and caused significant harm to herself and/or her baby, the risks of discontinuation may outweigh the risks of continuation, though even in such an extreme case, careful dose reduction may also be an option.

In rare situations where sodium valproate prescription continues during pregnancy, use should be restricted to monotherapy [81] and at the lowest dose possible [56, 76].

\section{A role for shared decision-making?}

In view of the new regulations requiring a woman of childbearing age to sign a risk acceptance form if she chooses to continue valproate, informed decision-making is more important than ever.

Shared decision-making is a process whereby health professionals and patients work together to make healthcare choices [82]. When deciding which treatments are appropriate, a discussion should involve the patient, with the clinician guiding them through the benefits and risks in order to make an informed decision [83]. Policymakers have called for increased collaboration between patients and clinicians [84], and patients are more likely to adhere to a healthcare decision if they have been involved in the process [85].

Legare et al. have carried out a narrative review of the literature on shared decision-making, and systematically debunked various myths regarding it. These include the assumptions that it takes longer to carry out in consultations, costs more money, or that it is incompatible with following clinical practice guidelines [82]. The authors also show that contrary to many clinicians' expectations, vulnerable patients who appear passive tend to gain more clinical benefit than those whose decision is made for them.

There is a wide variety of evidence-based tools to support shared decision-making during the clinical encounter [86], and some of these have been trialled successfully in specific diseases. For example, the talk model, developed by Elwyn et al. [87], improves treatment concordance and decision quality in epilepsy management, specifically for situations like pregnancy and medication withdrawal [84]. The model involves three kinds of talk: (1) team talk, where the patient is encouraged to consider different management strategies (e.g. valproate vs. levetiracetam for epilepsy); (2) option talk, where more detailed information about the options is provided (typically using an 'option grid' - a matrix structured around questions the patient might ask and covering all potential options for a particular set of circumstances), and (3) decision talk, where the clinician assists the patient with decisions by providing facts, figures and risks [87].

The talk model maps well to questions around valproate use in which women who are pregnant (or planning on becoming pregnant). The clinician should firstly present the different management options. These would include: (1) continuing the drug at the current dose, (2) titrating down to a lower dose, (3) discontinuing the drug, or (4) changing to a different medication. To support more detailed conversations, a matrix of options could be offered (see example in Table 5).

The third step in the talk model would be for the patient to discuss their preferred option with the clinician in detail, which would involve getting a more accurate picture of the risks involved. For example, if the woman chooses to discontinue valproate (column 4 in Table 3) the clinician should outline that this still presents risks to the baby, with the potential for the mother to become mentally unwell and hence perhaps neglect herself and her baby, leading in extreme cases to separation via social services. As noted above, the precise risks of this eventuality will depend on the medical and sociodemographic details of the individual case. It is hoped that in most cases clinician and patient will be able to collaboratively weigh up the pros and cons and achieve a decision that takes account of both mother and baby's health.

The question of shared decision-making for a teratogenic drug in pregnancy raises an ethical conundrum. Whilst the mother may choose to continue valproate (e.g. if her bipolar disorder or epilepsy is well-controlled on it), the foetus has no chance to express a view. Arguably, a 'paternalistic' decision by the clinician to discontinue (or not commence) valproate in a pregnant woman is actually a form of advocacy for a second patient (the foetus). Others might argue that this line of reasoning presupposes that a) the foetus will necessarily come to less harm overall if valproate is not given (in reality the balance of benefits versus harms may be more complex); and b) the mother will be motivated by self-interest rather than taking her unborn child's needs into account. 
Table 5 List of frequently asked questions and management options to support shared decision-making regarding valproate use for bipolar disorder before or during pregnancy

\begin{tabular}{|c|c|c|c|c|}
\hline $\begin{array}{l}\text { Frequently } \\
\text { asked } \\
\text { questions }\end{array}$ & $\begin{array}{l}\text { Continuing the current dose of } \\
\text { valproate }\end{array}$ & Lowering the dose of valproate & Discontinuing valproate & Changing to another medication \\
\hline $\begin{array}{l}\text { What does } \\
\text { it involve? }\end{array}$ & $\begin{array}{l}\text { No change to medication or } \\
\text { dose }\end{array}$ & $\begin{array}{l}\text { Over a period of weeks to } \\
\text { months, decreasing the } \\
\text { amount of valproate }\end{array}$ & $\begin{array}{l}\text { Over a period of weeks to } \\
\text { months, gradually stopping } \\
\text { valproate }\end{array}$ & $\begin{array}{l}\text { Switching to a different medication } \\
\text { (e.g. lamotrigine or an } \\
\text { antipsychotic) }\end{array}$ \\
\hline $\begin{array}{l}\text { What are } \\
\text { the risks to } \\
\text { me? }\end{array}$ & Usual side effects of valproate & $\begin{array}{l}\text { Usual side effects of valproate, } \\
\text { potential for relapse }\end{array}$ & $\begin{array}{l}\text { Higher risk of relapse } \\
\text { (depends on a variety of } \\
\text { factors - discuss with your } \\
\text { clinician), increased risk of } \\
\text { puerperal psychosis }\end{array}$ & $\begin{array}{l}\text { Risk of relapse if the other } \\
\text { medication is not as effective as } \\
\text { valproate; risk of new side effects }\end{array}$ \\
\hline $\begin{array}{l}\text { What are } \\
\text { the risks to } \\
\text { my baby? }\end{array}$ & $\begin{array}{l}\text { Congenital malformations (see } \\
\text { Table 4) long-term developmen- } \\
\text { tal disorders (estimated one in 3) }\end{array}$ & $\begin{array}{l}\text { Reduced risk of congenital } \\
\text { malformations and } \\
\text { developmental disorders (risk } \\
\text { depends on the dose, discuss } \\
\text { with your clinician) }\end{array}$ & $\begin{array}{l}\text { Indirect risks, e.g. disinhibition } \\
\text { from poorly controlled } \\
\text { bipolar disorder (discuss with } \\
\text { your clinician) }\end{array}$ & $\begin{array}{l}\text { Some medications are much safer } \\
\text { for your unborn baby (specifically } \\
\text { lamotrigine, some antipsychotics) }\end{array}$ \\
\hline $\begin{array}{l}\text { What are } \\
\text { the } \\
\text { benefits? }\end{array}$ & $\begin{array}{l}\text { You are less likely to relapse or } \\
\text { suffer from puerperal psychosis }\end{array}$ & $\begin{array}{l}\text { Your unborn baby will have a } \\
\text { lower risk of malformations } \\
\text { than if you continue the full } \\
\text { dose }\end{array}$ & $\begin{array}{l}\text { Your unborn baby will have } \\
\text { the same risk of } \\
\text { malformations as the general } \\
\text { population }\end{array}$ & $\begin{array}{l}\text { If you can tolerate the new drug, } \\
\text { you are less likely to relapse or } \\
\text { suffer from puerperal psychosis; the } \\
\text { other medication could have } \\
\text { adverse effects }\end{array}$ \\
\hline $\begin{array}{l}\text { Who } \\
\text { would } \\
\text { benefit } \\
\text { most from } \\
\text { this? }\end{array}$ & $\begin{array}{l}\text { People with unstable bipolar } \\
\text { disorder and frequent relapses } \\
\text { who are not controlled on other } \\
\text { medication or lower doses of } \\
\text { valproate }\end{array}$ & $\begin{array}{l}\text { People with bipolar disorder } \\
\text { who are not controlled on } \\
\text { other medication }\end{array}$ & $\begin{array}{l}\text { People who have been stable } \\
\text { off valproate and do not wish } \\
\text { to take other medications } \\
\text { during pregnancy }\end{array}$ & $\begin{array}{l}\text { People who are stable on } \\
\text { alternatives to valproate }\end{array}$ \\
\hline
\end{tabular}

\section{The future}

Given the limited evidence base on the precise benefits and harms associated with alternatives to sodium valproate during pregnancy, randomised controlled trials to assess their relative efficacies and safety profiles are justified. Various such trials are ongoing.

Personalised (that is, stratified) medicine offers some potential avenues for further research. One study has demonstrated that specific maternal and foetal genotypes in mice confer a greater susceptibility to the teratogenic effects of valproate [88], and may mean that in the future, some human genotypes could be preselected for continuing (or not continuing) the drug during pregnancy. More speculatively, environmental factors may predict susceptibility to valproate-induced teratogenicity. Ogawa et al. showed that geographical stressors, in particular the location of conception, significantly affected pregnant rats' sensitivity to teratogenicity during valproate use [89]. However, in general the hope for stratified solutions has greatly exceeded the clinical benefit of such solutions, so we should remain cautious about such options [90].

\section{Conclusion}

The management of bipolar disorder and epilepsy during pregnancy continues to carry complex challenges. Sodium valproate use is a growing issue in women of childbearing age, and patients and clinicians may well be faced with a situation in which they must weigh up the benefits and harms of continuation.
Although the teratogenic and long-term neurodevelopmental effects of valproate are now well established, the current evidence suggests that the recent strengthening of regulatory restrictions on its use are justified. However, it would be premature to ban the use of this drug in women of childbearing age in the UK (since in rare cases the benefits of its use may outweigh potential harms). In the light of the new regulatory framework, we believe that informed, democratic conversations are needed and we have provided an evidence-based framework to support shared decision-making. More research should be undertaken on how shared decision-making plays out in this group of patients, as well as on the efficacy and safety of the various alternatives to sodium valproate in bipolar disorder and epilepsy.

\section{Abbreviations \\ ANSM: French National Agency for the Safety of Medicines and Health Products; EURAP: International Registry of Anti-Epileptic Drugs and Preg- nancy; MHRA: Medicines and Healthcare Devices Regulatory Agency; NNT: Number Needed to Treat}

\section{Acknowledgements}

We thank the two reviewers for exceptionally helpful and detailed comments on a previous version of this paper, including suggestions for additional books and papers to include.

Funding

TG's contribution was part funded by the National Institute for Health Research Biomedical Research Centre, Oxford, grant BRC-1215-20008. 


\section{Authors' contributions}

AM carried out a narrative review of the literature to formulate the debate article and drafted the manuscript. TG checked the first draft, redrafted some paragraphs and suggested additional references. Both authors contributed to revising the paper. Both authors have given approval for the work to be published, and agree to be jointly accountable for all aspects of the work.

\section{Authors' information}

Alastair Macfarlane MA, MBBS is an Academic Foundation Year 1 doctor working at the Royal Free Foundation Trust. He is currently working in psychiatry at the Springwell Centre, Barnet Hospital. Trisha Greenhalgh FMedSci is a GP and Professor of Primary Care Health Sciences at the University of Oxford.

\section{Ethics approval and consent to participate} N/A

\section{Competing interests}

The authors declare that they have no competing interests.

\section{Publisher's Note}

Springer Nature remains neutral with regard to jurisdictional claims in published maps and institutional affiliations.

\section{Author details}

${ }^{1}$ Academic Foundation Year 1 Doctor, Barnet Hospital, Wellhouse Lane, Barnet EN5 3DJ, UK. ²Department of Primary Care Health Sciences, University of Oxford, Radcliffe Primary Care Building, Woodstock Road, Oxford OX2 $6 \mathrm{GG}, \mathrm{UK}$

Received: 8 November 2017 Accepted: 22 May 2018

Published online: 01 June 2018

\section{References}

1. Vargesson N. Thalidomide-induced limb defects: resolving a 50-year-old puzzle. Bioessays. 2009;31(12):1327-36.

2. Casassus B: France bans sodium valproate use in case of pregnancy. Lancet 2017, 390(10091):217-217.

3. Epilepsy in Pregnancy. Green Top Guidelines. Royal College of Obstetricians and Gynaecologists. 2016:68.

4. National Institute of Health and Clinical Excellence: Bipolar disorder: Assessment and management. In., vol. Clinical guideline CG185; 2014.

5. Wieck A. Dangers of valproate in pregnancy. BMJ. 2018;361:1609.

6. lacobucci G. MHRA bans valproate prescribing for women not in pregnancy prevention programme. BMJ. 2018:361, 1823

7. Nevitt SJ, Sudell M, Weston J, Smith CT, Marson AG. Antiepileptic drug monotherapy for epilepsy: a network meta-analysis of individual participant data. Cochrane Database Syst Rev. 2017;6:237.

8. Moller HJ, Nasrallah HA. Treatment of bipolar disorder. J Clin Psychiatry. 2003;64:9-17.

9. Molgaard-Nielsen D, Hviid A. Newer generation antiepileptic drugs and the risk of major birth defects. JAMA-J Am Med Assoc. 2011;305(19):1996-2002.

10. Schmidt D, Schachter SC. Drug treatment of epilepsy in adults. BMJ-British Medical Journal. 2014;348:18

11. Atturu $\mathrm{H}$, Odelola A. Valproate prescribing in women of childbearing age: an audit of clinical practice. Advances in Psychiatry. 2015;2015:1-6.

12. Murphy S, Bennett K, Doherty CP. Prescribing trends for sodium valproate in Ireland. Seizure. 2016;36:44-8.

13. Kaplan YC, Abdelkader N. Valproate prescribing trends for non-epilepsy indications in women of reproductive age warrants effective measures and increased surveillance. Seizure. 2016;40:13-4.

14. Swann AC. What is bipolar disorder? Am J Psychiat. 2006;163(2):177-9.

15. Weissman MM, Bland RC, Canino GJ, Faravelli C, Greenwald S, Hwu HG, Joyce PR, Karam EG, Lee CK, Lellouch J, et al. Cross-national epidemiology of major depression and bipolar disorder. Jama-Journal of the American Medical Association. 1996:276(4):293-9.

16. Pompili M, Gonda X, Serafini G, Innamorati M, Sher L, Amore M, Rihmer Z, Girardi P. Epidemiology of suicide in bipolar disorders: a systematic review of the literature. Bipolar Disord. 2013;15(5):457-90.
17. Hunt GE, Malhi GS, Cleary M, Lai HMX, Sitharthan T. Prevalence of comorbid bipolar and substance use disorders in clinical settings, 1990-2015. systematic review and meta-analysis. J Affect Disord. 2016;206:331-49.

18. Di Florio A, Craddock N, van den Bree M. Alcohol misuse in bipolar disorder: a systematic review and meta-analysis of comorbidity rates. Eur Psychiat. 2014;29(3):117-24.

19. Amerio A, Odone A, Liapis CC, Ghaemi SN. Diagnostic validity of comorbid bipolar disorder and obsessive compulsive disorder: a systematic review. Acta Psychiatr Scand. 2014;129(5):343-58.

20. Wingo AP, Ghaemi SN. A systematic review of rates and diagnostic validity of comorbid adult attention deficit hyperactivity disorder and bipolar disorder. J Clin Psychiatry. 2007;68(11):1776-84.

21. Simon NM, Otto MW, Wisniewski SR, Fossey M, Sagduyu K, Frank E, Sachs GS, Nierenberg AA, Thase ME, Pollack MH, et al. Anxiety disorder comorbidity in bipolar disorder patients: data from the first 500 participants in the systematic treatment enhancement program for bipolar disorder (STEP-BD). Am J Psychiat. 2004:161(12):2222-9.

22. Kupfer DJ, Frank E, Grochocinski VJ, Cluss PA, Houck PR, Stapf DA. Demographic and clinical characteristics of individuals in a bipolar disorder case registry. J Clin Psychiatry. 2002;63(2):120-5.

23. Viguera AC, Cohen LS, Baldessarini RJ, Nonacs R. Managing bipolar disorder during pregnancy: weighing the risks and benefits. Can J Psychiatr. 2002; 47(5):426-36.

24. Fisher RS, Boas W, Blume W, Elger C, Genton P, Lee P, Engel J. Epileptic seizures and epilepsy: definitions proposed by the international league against epilepsy (ILAE) and the International Bureau for Epilepsy (IBE). Epilepsia. 2005;46(4):470-2

25. Sander JW. The epidemiology of epilepsy revisited. Curr Opin Neurol. 2003; 16(2):165-70.

26. Zupanc ML. Antiepileptic drugs and hormonal contraceptives in adolescent women with epilepsy. Neurology. 2006;66(6):S37-45

27. Tomson T. Seizure control and treatment in pregnancy: observations from the EURAP epilepsy pregnancy registry. Neurology. 2006;66(3):354-60.

28. Petersen I, Collings SL, McCrea RL, Nazareth I, Osborn DP, Cowen PJ, Sammon CJ. Antiepileptic drugs prescribed in pregnancy and prevalence of major congenital malformations: comparative prevalence studies. Clin Epidemiol. 2017;9:95-103.

29. Ketter TA, Calabrese JR. Stabilization of mood from below versus above baseline in bipolar disorder: a new nomenclature. J Clin Psychiatry. 2002 63(2):146-51.

30. Taylor D, Paton C, Kapur S: Maudsley prescribing guidelines, Tenth Edition; 2009.

31. Nasrallah HA, Ketter TA, Kalali AH. Carbamazepine and valproate for the treatment of bipolar disorder: a review of the literature. J Affect Disord. 2006:95(1-3):69-78.

32. Pope HG, McElroy SL, Keck PE, Hudson Jl. Valproate in the treatment of acute mania: a placebo controlled study. Arch Gen Psychiatry. 1991:48(1):62-8.

33. Miura T, Noma H, Furukawa TA, Mitsuyasu H, Tanaka S, Stockton S, Salanti G, Motomura K, Shimano-Katsuki S, Leucht S, et al. Comparative efficacy and tolerability of pharmacological treatments in the maintenance treatment of bipolar disorder: a systematic review and network meta-analysis. Lancet Psychiatry. 2014;1(5):351-9.

34. Popovic D, Reinares M, Goikolea JM, Bonnin CM, Gonzalez-Pinto A, Vieta E. Polarity index of pharmacological agents used for maintenance treatment of bipolar disorder. Eur Neuropsychopharmacol. 2012;22(5):339-46.

35. Boden R, Lundgren M, Brandt L, Reutfors J, Andersen M, Kieler H. Risks of adverse pregnancy and birth outcomes in women treated or not treated with mood stabilisers for bipolar disorder: population based cohort study. $\mathrm{Br}$ Med J. 2012;345:10.

36. Grover S, Avasthi A. Mood stabilizers in pregnancy and lactation. Indian J Psychiatry. 2015;57:S308-23.

37. Trinka E. Ideal characteristics of an antiepileptic drug: how do these impact treatment decisions for individual patients? Acta Neurol Scand. 2012;126:10-8.

38. Pagano HP, Zapata LB, Berry-Bibee EN, Nanda K, Curtis KM. Safety of hormonal contraception and intrauterine devices among women with depressive and bipolar disorders: a systematic review. Contraception. 2016; 94(6):641-9.

39. Wyszynski DF, Nambisan M, Surve T, Alsdorf RM, Smith CR, Holmes LB, Antiepileptic Drug Pregnancy R. Increased rate of major malformations in offspring exposed to valproate during pregnancy. Neurology. 2005: 64(6):961-5 
40. Thisted E, Ebbesen F. Malformations, withdrawal manifestations and hypoglycaemia after exposure to valproate in utero. Arch Dis Child. 1993; 69(3):288-91.

41. Ornoy A. Valproic acid in pregnancy: how much are we endangering the embryo and fetus? Reprod Toxicol. 2009;28(1):1-10.

42. Semmler A, Frisch C, Bleul C, Smith D, Bigler L, Prost JC, Blom H, Linnebank M. Intrauterine valproate exposure is associated with alterations in hippocampal cell numbers and folate metabolism in a rat model of valproate teratogenicity. Seizure. 2017;46:7-12.

43. Roullet FI, Lai JKY, Foster JA. In utero exposure to valproic acid and autism: a current review of clinical and animal studies. Neurotoxicol Teratol. 2013; 36:47-56.

44. Bromley RL, Mawer GE, Briggs M, Cheyne C, Clayton-Smith J, Garica-Finana M, Kneen R, Lucas SB, Shallcross R, Baker GA, et al. The prevalence of neurodevelopmental disorders in children prenatally exposed to antiepileptic drugs. J Neurol Neurosurg Psychiatry. 2013;84(6):637-43.

45. Arkilo D, Vaou EO. Antiepileptic drug use during pregnancy: sodium valproate is associated with lower offspring $I Q$. Evidence-based nursing. 2015;18(4):109.

46. Schneider T, Przewlocki R. Behavioral alterations in rats prenatally exposed to valproic acid: animal model of autism. Neuropsychopharmacology. 2005; 30(1):80-9.

47. Ranger $P$, Ellenbroek BA. Perinatal influences of valproate on brain and behaviour: an animal model for autism. Curr Top Behav Neurosci. 2016;29: 363-86.

48. Williams G, King J, Cunningham M, Stephan M, Kerr B, Hersh JH. Fetal valproate syndrome and autism: additional evidence of an association. Dev Med Child Neurol. 2001;43(3):202-6.

49. Beezhold JN, Fagard D, Harabajiu C: Valproate used during pregnancy: what should be done? Eur Psychiat 2017, 41:S419-S419.

50. Briggs $G$, Freeman R. Drugs in pregnancy and lactation, 11th edition: Wolters: Kluwer; 2017

51. Ingram JL, Peckham SM, Tisdale B, Rodier PM. Prenatal exposure of rats to valproic acid reproduces the cerebellar anomalies associated with autism. Neurotoxicol Teratol. 2000;22(3):319-24.

52. Yang EJ, Ahn S, Lee K, Mahmood U, Kim HS. Early behavioral abnormalities and perinatal alterations of PTEN/AKT pathway in valproic acid autism model mice. PLoS One. 2016:11(4):17.

53. Jentink J, Loane MA, Dolk H, Barisic I, Garne E, Morris JK, den Berg LTW d Jv. Workin EAS: Valproic acid monotherapy in pregnancy and major congenital malformations Acid Monotherapy in Pregnancy and Major Congenital Malformations. N Engl J Med. 2010;362(23):2185-93.

54. Alsdorf R, Wyszynski DF. Teratogenicity of sodium valproate. Expert Opin Drug Saf. 2005:4(2):345-53.

55. Vajda FJ, O'Brien TJ, Hitchcock A, Graham J, Cook M, Lander C, Eadie MJ. Critical relationship between sodium valproate dose and human teratogenicity: results of the Australian register of anti-epileptic drugs in pregnancy. J Clin Neurosci. 2004;11(8):854-8.

56. Diav-Citrin O, Shechtman S, Bar-Oz B, Cantrell D, Arnon J, Ornoy A. Pregnancy outcome after in utero exposure to valproate: evidence of dose relationship in teratogenic effect. CNS Drugs. 2008:22(4):325-34.

57. Viguera AC, Whitfield T, Baldessarini RJ, Newport DJ, Stowe Z, Reminick A, Zurick A, Cohen LS. Risk of recurrence in women with bipolar disorder during pregnancy: prospective study of mood stabilizer discontinuation. Am J Psychiat. 2007;164(12):1817-24.

58. Stewart DE. Prophylactic lithium in postpartum affective psychosis. J Nerv Ment Dis. 1988;176(8):485-9.

59. Stewart DE, Klompenhouwer JL, Kendell RE, Vanhulst AM. Prophylactic lithium in puerperal psychosis: the experience of 3 centres. Br J Psychiatry. 1991;158:393-7.

60. Austin MPV. Puerperal affective psychosis: is there a case for lithium prophylaxis? Br J Psychiatry. 1992;161:692-4.

61. Howland RH. Potential adverse effects of discontinuing psychotopic drugs part 1: adrenergic cholergic and histamine drugs. J Psychosoc Nurs Ment Health Serv. 2010;48(6):11-4.

62. Sharma P, Kongasseri S, Praharaj SK. Outcome of mood stabiliser discontinuation in bipolar disorder after 5 years of euthymia. J Clin Psychopharmacol. 2014;34(4):504-7.

63. Cipriani A, Reid K, Young AH, Macritchie K, Geddes J. Valproic acid, valproate and divalproex in the maintenance treatment of bipolar disorder. Cochrane Database Syst Rev. 2013;10:76.
64. Koksal A, Dirican AC, Altunkaynak Y, Yildirim EA. First manic episode due to discontinuation of valproic acid in a patient with epilepsy. J Neuropsychiatr Clin Neurosci. 2014;26(2):E60-1.

65. Tomson T, Battino D, Bonizzoni E, Craig J, Lindhout D, Perucca E, Sabers A, Thomas SV, Vajda F, Grp ES. Withdrawal of valproic acid treatment during pregnancy and seizure outcome: observations from EURAP. Epilepsia. 2016; 57(8):E173-7.

66. Kendell RE, Chalmers JC, Platz C. Epidemiology of puerperal psychoses. Br J Psychiatry. 1987;150:662-73.

67. Harlow BL, Vitonis AF, Sparen P, Cnattingius S, Joffe $H$, Hultman CM. Incidence of hospitalization for postpartum psychotic and bipolar episodes in women with and without prior prepregnancy or prenatal psychiatric hospitalizations. Arch Gen Psychiatry. 2007:64(1):42-8.

68. Bucove AD. A case of prepartum psychosis and infanticide. Psychiatr Q. 1968;42(2):263.

69. Friedman SH, Sorrentino R. Postpartum psychosis, infanticide, and insanity: implication for forensic psychiatry. J Am Acad Psychiatry Law. 2012;40(3): 326-32.

70. Kapfhammer H-P, Lange P. Suicidal and infanticidal risks in puerperal psychosis of an early onset. Neuropsychiatrie : Klinik, Diagnostik, Therapie und Rehabilitation : Organ der Gesellschaft Osterreichischer Nervenarzte und Psychiater. 2012;26(3):129-38.

71. Hollins K. Consequences of antenatal mental health problems for child health and development. Curr Opin Obstet Gynecol. 2007;19(6):568-72.

72. Garcia-Portilla MP, Bobes J. Preventive recommendations on the use of valproic acid in pregnant or gestational women to be very present. Rev Psiquiatr Salud Ment. 2017;10(3):129-33.

73. Kmietowicz Z. Women are unaware of pregnancy risks linked with sodium valproate. BMJ. 2016;355:2

74. Black Kl, Day CA. Improving access to long acting contraceptive methods and reducing unplanned pregnancy among women with substance use disorders. Substance Abuse Research and Treatment. 2016;10:27-33.

75. Johnson BR, Ndhlovu S, Farr SL, Chipato T. Reducing unplanned pregnancy and abortion in Zimbabwe through postabortion contraception. Stud Fam Plan. 2002;33(2):195-202.

76. Tomson T, Battino D, Bonizzoni E, Craig J, Lindhout D, Perucca E, Sabers A, Thomas SV, Vajda F, Grp ES. Dose dependent teratogenicity of valproate in mono- and polytherapy: an observational study. Neurology. 2015:85(10):866-72.

77. McGirr A, Vohringer PA, Ghaemi SN, Lam RW, Yatham LN. Safety and efficacy of adjunctive second-generation antidepressant therapy with a mood stabiliser or an atypical antipsychotic in acute bipolar depression: a systematic review and meta-analysis of randomised placebo-controlled trials. Lancet Psychiatry. 2016;3(12):1138-46.

78. Huybrechts KF, Hernandez-Diaz S, Patorno E, Desai RJ, Mogun H, Dejene SZ, Cohen JM, Panchaud A, Cohen L, Bateman BT. Antipsychotic use in pregnancy and the risk for congenital malformations. JAMA Psychiatry. 2016;73(9):938-46.

79. Kaplan Y. Lamotrigine for epilepsy may not increase risk of birth defects, study shows. BMJ. 2016;353

80. Larsen ER, Saric K. Pregnancy and bipolar disorder: the risk of recurrence when discontinuing treatment with mood stabilisers: a systematic review. Acta neuropsychiatrica. 2016:1-8.

81. Stephen LJ, Forsyth M, Kelly K, Brodie MJ. Antiepileptic drug combinations: have newer agents altered clinical outcomes? Epilepsy Res. 2012;98(2-3): 194-8.

82. Legare $F$, Thompson-Leduc $P$. Twelve myths about shared decision making. Patient Educ Couns. 2014;96(3):281-6.

83. Herxheimer A. Communicating with patients about harms and risks. PLoS Med. 2005;2(2):91-2.

84. Pickrell WO, Elwyn G, Smith PEM. Shared decision making in epilepsy management. Epilepsy Behav. 2015:47:78-82.

85. Joosten EAG, DeFuentes-Merillas L, de Weert GH, Sensky T, van der Staak CPF, de Jong CAJ. Systematic review of the effects of shared decisionmaking on patient satisfaction, treatment adherence and health status. Psychother Psychosom. 2008;77(4):219-26.

86. Austin CA, Mohottige D, Sudore RL, Smith AK, Hanson LC. Tools to promote shared decision making in serious illness: a systematic review. JAMA Intern Med. 2015;175(7):1213-21.

87. Elwyn G, Frosch D, Thomson R, Joseph-Williams N, Lloyd A, Kinnersley P, Cording E, Tomson D, Dodd C, Rollnick S, et al. Shared decision making: a model for clinical practice. J Gen Intern Med. 2012;27(10):1361-7. 
88. Downing C, Biers J, Larson C, Kimball A, Wright H, Ishii T, Gilliam D, Johnson T. Genetic and maternal effects on valproic acid teratogenesis in C57BL/6J and DBA/2J mice. Toxicol Sci. 2010;116(2):632-9.

89. Ogawa T, Kuwagata M, Hori Y, Shioda S. Valproate-induced developmental neurotoxicity is affected by maternal conditions including shipping stress and environmental change during early pregnancy. Toxicol Lett. 2007; 174(1-3):18-24.

90. Dammann M, Weber F. Personalized medicine: caught between hope, hype and the real world. Clinics. 2012;67:91-7.

91. Lenox RH, Hahn CG. Overview of the mechanism of action of lithium in the brain: fifty-year update. J Clin Psychiatry. 2000;61:5-15.

92. Loscher W. Valproate: a reappraisal of its pharmacodynamic properties and mechanisms of action. Prog Neurobiol. 1999:58(1):31-59.

93. Johannessen CU. Mechanisms of action of valproate: a commentatory. Neurochem Int. 2000;37(2-3):103-10.

94. Xie XM, Hagan RM. Cellular and molecular actions of lamotrigine: possible mechanisms of efficacy in bipolar disorder. Neuropsychobiology. 1998;38(3): 119-30.

95. Ambrosio AF, Soares-da-Silva P, Carvalho CM, Carvalho AP. Mechanisms of action of carbamazepine and its derivatives, oxcarbazepine, BIA 2-093, and BIA 2-024. Neurochem Res. 2002;27(1-2):121-30.

96. Post RM, Rubinow DR, Unde TW. Biochemical mechanisms of action of carbamazepine in affective illness and epilepsy. Psychopharmacol Bull. 1984; 20(3):585-9.

97. Hertel P, Lindblom N, Nomikos GG, Svensson TH. Modulation of central serotonergic neurotransmission by risperidone: underlying mechanism s and significance of action. Prog Neuro-Psychopharmacol Biol Psychiatry. 1998;22(5):815-34

98. Di Martino A, Zuddas A. Long-term risperidone treatment in pervasive developmental disorders: efficacy, safety, and putative mechanism of action. Consensus in Child Neurology. 2003:82-7.

99. Li XM, Juorio AV, Chlan-Founey J, Shrikhande S, Bennett VL, Keegan DL. A new mechanism for the actions of olanzapine. Can J Psychiat-Rev Can Psychiat. 1999;44(6):605-6.

100. Goldstein JM: Mechanism of action of quetiapine: a modulator of dopamine at the D2 receptor. Schizophr Res 2003, 60(1):311-311.

101. Patorno E, Huybrechts KF, Bateman BT, Cohen JM, Desai RJ, Mogun H, Cohen LS, Hernandez-Diaz S. Lithium use in pregnancy and the risk of cardiac malformations. N Engl J Med. 2017;376(23):2245-54.

102. Morrell MJ. The new antiepileptic drugs and women: efficacy, reproductive health, pregnancy, and fetal outcome. Epilepsia. 1996;37:S34-44.

103. Matalon S, Schechtman S, Goldzweig G, Ornoy A. The teratogenic effect of carbamazepine: a meta-analysis of 1255 exposures. Reprod Toxicol. 2002; 16(1):9-17.

104. de Haan GJ, Edelbroek P, Segers J, Engelsman M, Lindhout D, DevileNotschaele M, Auqustijn P. Gestation-induced changes in lamotrigine pharmacokinetics: a monotherapy study. Neurology. 2004;63(3):571-3.

105. Tomson T, Battino D, Bonizzoni E, Craig J, Lindhout D, Sabers A, Perucca E, Vajda F, Grp ES. Dose dependent risk of malformations with antiepileptic drugs: an analysis of data from the EURAP epilepsy and pregnancy registry. Lancet Neurol. 2011;10(7):609-17.

106. Campbell E, Kennedy F, Russell A, Smithson WH, Parsons L, Morrison PJ, Liggan B, Irwin B, Delanty N, Hunt SJ, et al. Malformation risks of antiepileptic drug monotherapies in pregnancy: updated results from the UK and Ireland epilepsy and pregnancy registers. J Neurol Neurosurg Psychiatry. 2014;85(9):1029-34.

\section{Ready to submit your research? Choose BMC and benefit from:}

- fast, convenient online submission

- thorough peer review by experienced researchers in your field

- rapid publication on acceptance

- support for research data, including large and complex data types

- gold Open Access which fosters wider collaboration and increased citations

- maximum visibility for your research: over $100 \mathrm{M}$ website views per year

At BMC, research is always in progress.

Learn more biomedcentral.com/submissions 